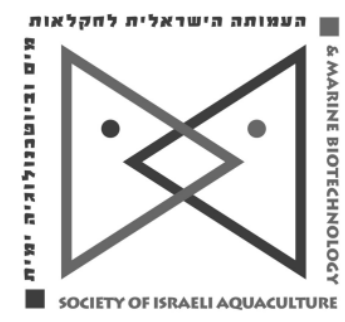

The IJA appears exclusively as a peer-reviewed on-line open access journal at http://www.siamb.org.il Sale of IJA papers is strictly forbidden.

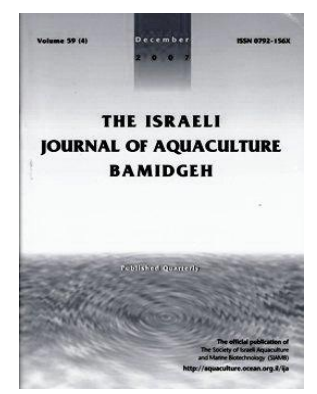

\title{
Effect of Dietary Selenium Supplementation on Cirrhinus mrigala (Hamilton, 1822) Reared in Copper and/or Cadmium Contaminated Water
}

\author{
Raja James \\ Postgraduate and Research Department of Zoology, V.O. Chidambaram \\ College, Tuticorin 628008, Tamil Nadu, India
}

(Received 28.4.10, Accepted 2.9.10)

Key words: selenium, heavy metals, physiological parameters, metal burden, elimination, Cirrhinus mrigala

\begin{abstract}
The effect of selenium supplementation at $0,75,150,225$, and $300 \mathrm{mg} / \mathrm{kg}$ diet on reduction of copper and/or cadmium toxicity was studied in a freshwater cultivated carp, Cirrhinus mrigala. Food utilization, selected hematological parameters, oxygen consumption, and metal concentrations in the fish body and fecal matter were analyzed. The 96-h $L C_{50}$ values for $C$. mrigala were $0.126 \mathrm{ppm}$ for copper exposure, $0.563 \mathrm{ppm}$ for cadmium, and $0.123 \mathrm{ppm}$ for exposure to both metals simultaneously. Sublethal exposures to the metals significantly reduced consumption and growth rates, hematological parameters, and oxygen consumption in fish fed the unsupplemented diet. Equitoxic exposure of copper and cadmium together drastically reduced the physiological parameters as compared to individual exposure to either one of the metals. However, dietary selenium supplementation significantly improved the tested physiological parameters and reduced the metal burden in the fish body. Metal elimination from the body took place through the feces. Supplementation of 75 and $225 \mathrm{mg}$ selenium per $\mathrm{kg}$ diet was required to reduce copper and cadmium toxicity when the metals existed individually in the environment. However, $300 \mathrm{mg}$ selenium per $\mathrm{kg}$ diet was required to reduce toxicity when both metals were present together in the environment.
\end{abstract}

* Corresponding author. E-mail: piojames@yahoo.com 


\section{Introduction}

Carps play a major role in the freshwater aquaculture of India. Cirrhinus mrigala is one of the important aquacultured carp species, not only in India but also throughout Asia. Addition of certain nutrients can increase feed utility and help to remove copper in fish (James et al., 2006; James, 2010). Copper (Cu) and cadmium (Cd) are the most commonly used metals in aquaculture and the most common contaminants in freshwater systems (James and Sampath, 1995; Adhikari, 2002; Liu and Yang, 2009). From the point of view of human consumption, the complete removal of toxic elements in the fish body is of utmost importance (Boyd, 1990; James et al., 1998). Selenium (Se) is an essential dietary element, required for normal growth and physiological functioning in fish (Hilton et al., 1980; Bell et al., 1985). Selenium also helps remove metals from the fish body (Abdel-Tawwab et al., 2007). Sodium selenite and sodium selenate, inorganic forms of Se, are commonly used as supplements in livestock diets. The present work was undertaken to study the effect of dietary supplementation of selenium on physiological parameters and copper and/or cadmium toxicity in the freshwater fish, C. mrigala.

\section{Materials and Methods}

Fish. Cirrhinus mrigala were collected from Manimuthar Dam, Tamil Nadu, and held for 30 days in laboratory conditions $\left(27.7 \pm 0.5^{\circ} \mathrm{C}, \mathrm{pH} 7.8 \pm 0.05\right.$, salinity $0.13 \mathrm{ppt}, 87 \mathrm{mg}$ $\mathrm{CaCO}_{3} / \mathrm{l}$, and dissolved oxygen $4.45 \mathrm{ml} \mathrm{O}_{2} / \mathrm{l}$ ) for acclimatization. During acclimatization, water was changed daily and fish were fed a pelletized diet containing $35 \%$ protein ad libitum.

Feeds. Feed ingredients (dried fishmeal, ground nut oil cake, cod liver oil, egg yolk, tapioca flour, vitamin and mineral mixtures) were combined in appropriate proportions by the Square method, which is commonly used to balance the crude protein level in the diet by incorporating different ingredients (Hardy, 1980). An appropriate amount of selenium $(0,75,150,225$, or $300 \mathrm{mg}$ selenium $/ \mathrm{kg}$ diet $)$ plus an aliquot of boiled water were added. The ingredients were mixed well and steam cooked for 15-20 min. After moderate cooling, 2-mm pellets were prepared with a hand operated pelletizer, dried in sunlight, and stored separately in a refrigerator. The resulting diet contained $35 \%$ protein.

Determination of 96- $h L C_{50}$. Stock solutions of copper and cadmium were separately prepared by dissolving $3.93 \mathrm{~g}$ analar grade (Merck) copper sulfate $\left(\mathrm{CuSO}_{4}: 7 \mathrm{H}_{2} \mathrm{O}\right)$ or $6.486 \mathrm{~g}$ cadmium sulfate $\left(\mathrm{CdSO}_{4}: 8 \mathrm{H}_{2} \mathrm{O}\right)$, respectively, in 1 I distilled water. The solutions were then diluted with fresh water to obtain the desired concentrations for the present study. Triplicate groups of six acclimated fish $(3.12 \pm 0.18 \mathrm{~g})$ were exposed to copper ( 0 , $0.05,0.10,0.15,0.20$, or $0.25 \mathrm{ppm})$ or cadmium $(0,0.25,0.50,1.00,1.25$, or 1.50 $\mathrm{ppm}$ ) and mortality was observed for $96 \mathrm{~h}$. In addition, equal amounts of the stock solutions were taken, different concentrations $(0,0.06,0.12,0.18,0.24$, and $0.30 \mathrm{ppm})$ were prepared, triplicate groups of six acclimated fish were exposed to the equitoxic concentrations, and mortality was observed for $96 \mathrm{~h}$. Thus, 324 fish (18 exposures $\times 3$ replicates $\times 6$ fish per replicate) were used to determine the median 96-h lethal concentration of the toxicants by a static renewable bioassay method (Sprague, 1973). The 96-h LC 50 was calculated by probit analysis (Litchfield and Wilcoxon, 1949). A control group was maintained in metal-free fresh water.

Effect of selenium on toxicity. The second series of experiment was conducted to study the effect of sodium selenite on the reduction of metal toxicity in C. mrigala based on chosen physiological parameters and metal distribution. Active C. mrigala (3.12 0.18 g) were selected from the stock and divided into 16 groups of 10 individuals each. They were not fed for $24 \mathrm{~h}$ prior to commencement of the experiment. The experiment was conducted in triplicate in epoxy-coated 110-I cement tanks containing 100 I water.

Group 1 served as the control and was reared in metal-free water. Fish in Groups 2, $3,4,5$, and 6 were exposed to $0.063 \mathrm{ppm}$ of copper for 30 days. Groups 1 and 2 were fed the unsupplemented diet. Fish in Groups 3, 4, 5, and 6 were fed diets containing 75, 150, 225, and $300 \mathrm{mg}$ sodium selenite/kg diet, respectively. Fish in Groups 7, 8, 9, 10, and 11 were exposed to $0.284 \mathrm{ppm}$ of cadmium for 30 days and were fed diets 
containing $0,75,150,225$, and $300 \mathrm{mg}$ sodium selenite/ $\mathrm{kg}$ diet, respectively. Fish in Groups 12, 1314,15 , and 16 were exposed to $0.051 \mathrm{ppm}$ of equitoxic concentrations of copper and cadmium for 30 days and were fed diets containing 0, 75, 150, 225, and 300 $\mathrm{mg}$ sodium selenite/kg diet, respectively. Water was not changed during the experiment but was aerated for $14 \mathrm{~h}$ to avoid oxygen depletion. Hydrobiological parameters were estimated once a week. Dissolved oxygen was $4.08 \pm 0.25 \mathrm{ml} \mathrm{O}_{2} / \mathrm{l}$, temperature $28.8 \pm 0.2^{\circ} \mathrm{C}$, pH $7.8 \pm 0.1$, salinity $0.32 \pm 02 \mathrm{ppt}$, and hardness $135 \mathrm{mg} \mathrm{CaCO} / \mathrm{l}$.

Feed consumption and specific growth rate. The fish were fed a weighed quantity of the experimental diets ad libitum in a feeding tray daily at 08:00 and 17:00. Unconsumed feed was collected $1 \mathrm{~h}$ after feeding and dried in a hot air oven at $80^{\circ} \mathrm{C}$ for two days. Feed consumption $(\mathrm{mg})$ was estimated by subtracting the amount of unconsumed dry feed from the dry weight of the offered feed. The feeding rate $(\mathrm{mg} / \mathrm{g}$ live fish/day) was computed as feed consumed/(initial wet wt of fish $\times$ no. days).

Fish were weighed at the beginning and at the end of the experiment. Growth (i.e., weight gain) was calculated as the difference between the wet weights at the beginning of the experiment and on the day of calculation. Specific growth rate (SGR; \%/day) was calculated as the difference between the wet weights at the beginning of the experiment and on the day of calculation as $100\left(\ln \mathrm{Wt}_{1}-\ln \mathrm{Wt}_{0}\right) / \mathrm{t}_{1}$, where $\ln \mathrm{Wt}_{0}$ and $\ln \mathrm{Wt}_{1}$ are the weights of the fish at the beginning and end of the experiment and $t_{1}$ is the period between sampling in days.

Fish, feed samples, unconsumed feed, and feces were weighed in an electric monopan balance to $1 \mathrm{mg}$ accuracy. Fecal matter was randomly collected before feedings using enamel trays and dried in a hot air oven at $60^{\circ} \mathrm{C}$ to estimate the copper and cadmium contents.

Blood parameters. Prior to commencement and at the end of the experiments, oxygen consumption, red blood corpuscle (RBC) count, hemoglobin content, and oxygen carrying capacity of the blood were estimated. At the end of the experiment, test animals were starved for $24 \mathrm{~h}$ before estimation. Three fish were removed from each experimental group on day 32. Oxygen consumption was estimated following Winkler's method (Welsh and Smith, 1953). Blood was collected in a watch glass containing the required amount of $6 \%$ EDTA as an anticoagulant by cutting the caudal peduncle using a sharp knife and hematological parameters were estimated according to routine clinical methods (Wintrobe, 1978). RBC were counted using an improved Neubauer counting chamber (Feinoptik Bad Blankenburg, Germany) and a hemoglobinometer (Marienfeld, Germany) was used to determine the hemoglobin content of blood. The oxygen carrying capacity of blood was calculated by multiplying the hemoglobin content by 1.25 , which is the oxygen combining power of $\mathrm{Hb} / \mathrm{g}$ (Johansen, 1970). Each parameter was estimated three times and data were subjected to Student's $t$ test. Correlation and regression analyses were used to find the relationship between the selenium diets and elimination of copper through feces (Zar, 1984).

Copper and cadmium content in fish. After estimating oxygen consumption and hematological parameters, the remaining fishes were sacrificed and dried in a hot air oven at $80^{\circ} \mathrm{C}$ to estimate copper and cadmium contents. Copper and cadmium contents in the fish body and in the feces were estimated on day 32. Three samples from each treatment were taken and digested in a water bath at $100^{\circ} \mathrm{C}$ with a mixture of concentrated nitric acid and perchloric acid (1:2) until a white residue formed. The cooled residue was completely dissolved by adding $1 \mathrm{~N} \mathrm{HCl}$ and made up to $25 \mathrm{ml}$ with distilled water (FAO, 1975). The solution was filtered through cotton wool and the filtrate was subjected to metal analysis in atomic absorption spectrophotometry (GBC Avantha model). The instrument was calibrated using standards prepared from copper and cadmium sulfates.

\section{Results}

The 96-h LC $_{50}$ values of copper, cadmium, and copper together with cadmium were $0.126,0.563$, and $0.123 \mathrm{ppm}$, respectively. Feeding and growth parameters were high in the control fish and significantly $(p<0.05)$ dropped in exposed fish fed the selenium-free 
diet (Table 1). However, the weight gain was enhanced in exposed fish fed seleniumsupplemented diets. Similar trends were obtained in the consumption rate, specific growth rate, hematological parameters, and rate of oxygen consumption.

Table 1. Effect of dietary selenium supplementation on feed utilization and hematological parameters in Cirrhinus mrigala exposed to sublethal levels of copper and/or cadmium (means $\pm S D ; n=3$ ).

\begin{tabular}{|c|c|c|c|c|c|c|c|c|}
\hline Exposure & $\begin{array}{c}\text { Feed } \\
\text { consumption } \\
\text { ( } g \text { dry matter) }\end{array}$ & $\begin{array}{c}\text { Consumption } \\
\text { rate } \\
\text { ( } \mathrm{mg} / \mathrm{g} \text { live } \\
\text { fish/day) }\end{array}$ & $\begin{array}{l}\text { Weight gain } \\
\text { ( } g \text { wet wt) }\end{array}$ & $\begin{array}{l}\text { Specific } \\
\text { growth } \\
\text { rate } \\
\text { (\%/day) }\end{array}$ & $\begin{array}{c}R B C \text { count } \\
\left(\times 10^{6} / \mathrm{mm}\right)\end{array}$ & $\begin{array}{c}H b \\
\text { content } \\
(g \%)\end{array}$ & $\begin{array}{c}\text { Oxygen } \\
\text { carrying } \\
\text { capacity of } \\
\text { blood } \\
\left(\mathrm{mg} \mathrm{O}_{2} / \mathrm{g} \mathrm{Hb}\right)\end{array}$ & $\begin{array}{c}\text { Oxygen } \\
\text { consumption } \\
\left(m g \mathrm{O}_{2} / g / h\right)\end{array}$ \\
\hline Control & $22.25 \pm 1.38$ & $68.89 \pm 2.67$ & $11.01 \pm 0.98$ & $6.70 \pm 0.36$ & $1.95 \pm 0.07$ & $6.20 \pm 0.22$ & $7.75 \pm 0.27$ & $0.53 \pm 0.11$ \\
\hline \multicolumn{9}{|l|}{ Copper } \\
\hline CuSeO & $13.32 \pm 1.01$ & $37.15 \pm 3.50$ & $3.01 \pm 0.13$ & $2.39 \pm 0.23$ & $0.80 \pm 0.05$ & $3.18 \pm 0.33$ & $4.00 \pm 0.08$ & $0.22 \pm 0.15$ \\
\hline CuSe1 & $19.65 \pm 1.75$ & $52.17 \pm 4.37$ & $7.49 \pm 0.15$ & $5.71 \pm 0.45$ & $1.58 \pm 0.04$ & $5.73 \pm 0.25$ & $7.17 \pm 0.31$ & $0.33 \pm 0.35$ \\
\hline CuSe2 & $16.59 \pm 1.33$ & $47.54 \pm 4.13$ & $6.04 \pm 0.14$ & $4.92 \pm 0.27$ & $1.28 \pm 0.07$ & $5.07 \pm 0.25$ & $6.33 \pm 0.31$ & $0.34 \pm 0.21$ \\
\hline CuSe3 & $14.94 \pm 1.45$ & $44.49 \pm 4.05$ & $4.04 \pm 0.13$ & $3.70 \pm 0.35$ & $0.96 \pm 0.02$ & $4.40 \pm 0.20$ & $5.59 \pm 0.26$ & $0.23 \pm 0.32$ \\
\hline CuSe4 & $17.10 \pm 1.58$ & $41.69 \pm 3.67$ & $5.04 \pm 0.21$ & $4.00 \pm 0.38$ & $0.94 \pm 0.09$ & $4.03 \pm 0.21$ & $5.00 \pm 0.20$ & $0.16 \pm 0.22$ \\
\hline \multicolumn{9}{|l|}{ Cadmium } \\
\hline $\mathrm{CdSeO}$ & $15.32 \pm 1.11$ & $40.42 \pm 3.55$ & $3.69 \pm 0.11$ & $2.73 \pm 0.07$ & $0.72 \pm 0.06$ & $3.43 \pm 0.17$ & $4.29 \pm 0.21$ & $0.18 \pm 0.06$ \\
\hline CdSe1 & $19.25 \pm 1.68$ & $49.00 \pm 4.23$ & $7.16 \pm 0.23$ & $5.00 \pm 0.17$ & $0.83 \pm 0.01$ & $4.47 \pm 0.21$ & $5.59 \pm 0.26$ & $0.28 \pm 0.27$ \\
\hline $\mathrm{CdSe} 2$ & $15.82 \pm 1.43$ & $51.37 \pm 5.18$ & $6.03 \pm 0.18$ & $4.62 \pm 0.35$ & $0.75 \pm 0.02$ & $4.63 \pm 0.16$ & $5.79 \pm 0.06$ & $0.37 \pm 0.15$ \\
\hline CdSe3 & $19.53 \pm 1.75$ & $59.33 \pm 4.17$ & $6.50 \pm 0.34$ & $5.44 \pm 0.28$ & $0.92 \pm 0.03$ & $4.90 \pm 0.33$ & $6.21 \pm 0.41$ & $0.38 \pm 0.31$ \\
\hline $\mathrm{CdSe} 4$ & $16.97 \pm 1.60$ & $49.86 \pm 3.95$ & $4.41 \pm 0.19$ & $3.47 \pm 0.30$ & $0.88 \pm 0.04$ & $4.17 \pm 0.12$ & $5.21 \pm 0.16$ & $0.26 \pm 0.42$ \\
\hline \multicolumn{9}{|c|}{ Copper + cadmium } \\
\hline $\mathrm{Cu}+\mathrm{Cd} \mathrm{SeO}$ & $7.14 \pm 0.17$ & $24.89 \pm 2.13$ & $2.20 \pm 0.07$ & $1.72 \pm 0.05$ & $0.25 \pm 0.06$ & $1.50 \pm 0.08$ & $1.88 \pm 0.10$ & $0.15 \pm 0.13$ \\
\hline $\mathrm{Cu}+\mathrm{Cd} \mathrm{Se} 1$ & $10.47 \pm 0.97$ & $30.31 \pm 2.60$ & $2.67 \pm 0.09$ & $2.23 \pm 0.15$ & $0.32 \pm 0.01$ & $2.00 \pm 0.21$ & $2.50 \pm 0.26$ & $0.17 \pm 0.11$ \\
\hline $\mathrm{Cu}+\mathrm{Cd} \mathrm{Se} 2$ & $11.10 \pm 1.01$ & $29.55 \pm 2.77$ & $3.13 \pm 0.12$ & $2.42 \pm 0.22$ & $0.40 \pm 0.03$ & $2.15 \pm 0.22$ & $2.69 \pm 0.27$ & $0.20 \pm 0.13$ \\
\hline $\mathrm{Cu}+\mathrm{Cd} \mathrm{Se} 3$ & $11.95 \pm 1.11$ & $39.62 \pm 3.19$ & $2.91 \pm 0.14$ & $2.92 \pm 0.28$ & $0.48 \pm 0.02$ & $2.47 \pm 0.08$ & $3.09 \pm 0.10$ & $0.27 \pm 0.22$ \\
\hline $\mathrm{Cu}+\mathrm{Cd} \mathrm{Se} 4$ & $13.06 \pm 1.07$ & $37.70 \pm 3.07$ & $3.56 \pm 0.17$ & $2.98 \pm 0.26$ & $0.53 \pm 0.01$ & $2.68 \pm 0.02$ & $3.35 \pm 0.16$ & $0.33 \pm 0.11$ \\
\hline
\end{tabular}

The control was reared in metal-free water and fed the unsupplemented diet. CuSe0-4 were exposed to 0.063 ppm of copper and fed diets containing $0,75,150,225$, and $300 \mathrm{mg}$ sodium selenite/kg diet, respectively, for 30 days. CdSe0-4 were exposed to $0.284 \mathrm{ppm}$ of cadmium and fed diets containing $0,75,150,225$, and 300 mg sodium selenite/kg diet, respectively, for 30 days. $\mathrm{Cu}+\mathrm{Cd} \mathrm{Se} 0-4$ were exposed to $0.051 \mathrm{ppm}$ of equitoxic concentrations of copper and cadmium and fed diets containing $0,75,150,225$, and $300 \mathrm{mg}$ sodium selenite/ $\mathrm{kg}$ diet, respectively, for 30 days.

Accumulation of $\mathrm{Cu}$ and $\mathrm{Cd}$ was significantly $(p<0.05)$ higher in $C$. mrigala fed the selenium-free diet and gradually decreased as the selenium in the diet increased (Fig. 1). The maximum reduction of copper and cadmium accumulation in the fish body occurred with the $75 \mathrm{mg}$ (CuSe1) and $225 \mathrm{mg}$ (CdSe3) supplementation diets, respectively, but
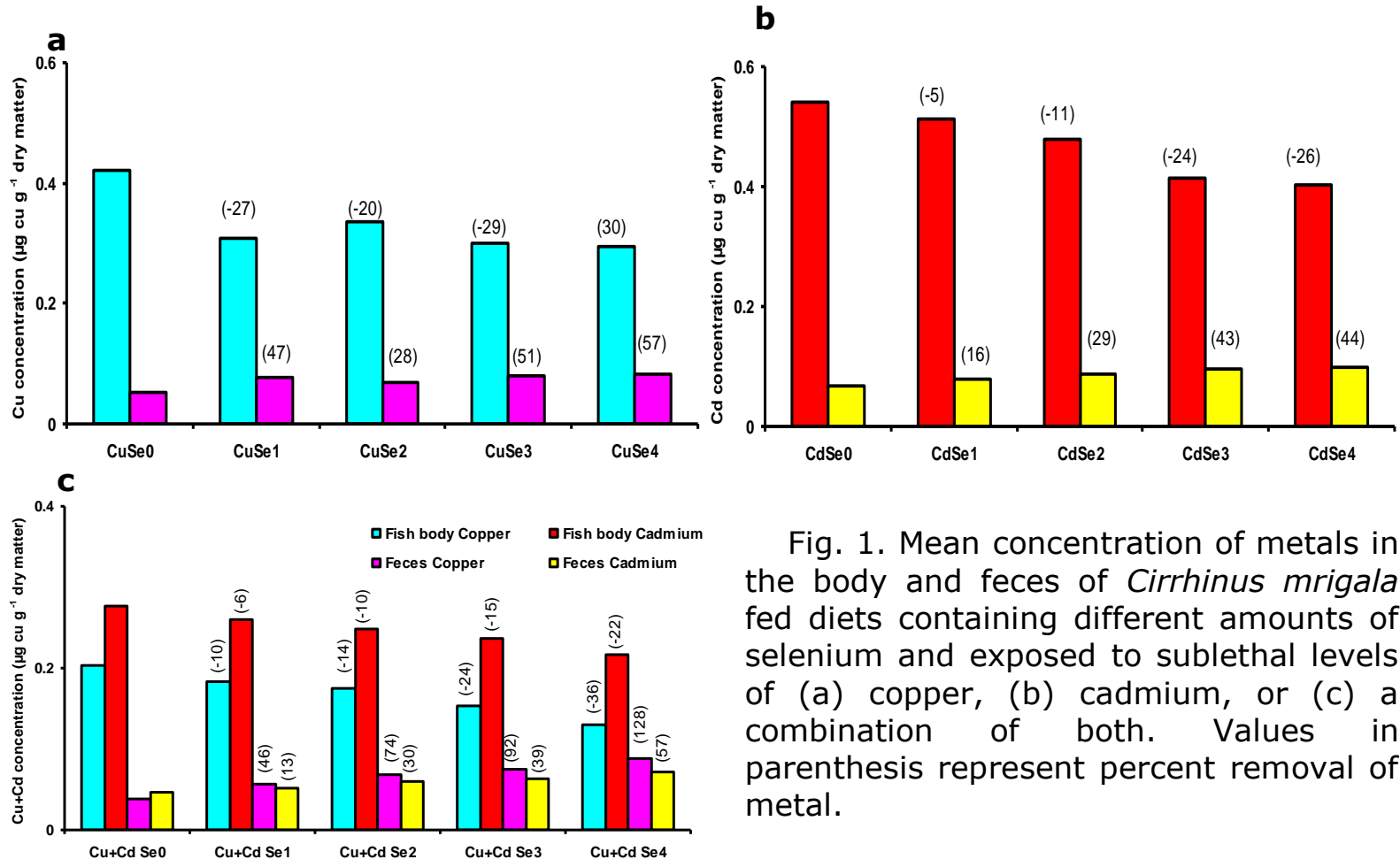

Fig. 1. Mean concentration of metals in the body and feces of Cirrhinus mrigala fed diets containing different amounts of selenium and exposed to sublethal levels of (a) copper, (b) cadmium, or (c) a combination of both. Values in parenthesis represent percent removal of metal. 
there were no significant $(p>0.05)$ differences with other groups. In the equitoxic exposure, the $300 \mathrm{mg}$ selenium diet $(\mathrm{Cu}+\mathrm{Cd} \mathrm{Se} 4)$ produced the maximum reduction of copper (36\% and $128 \%)$ and cadmium (22\% and $57 \%)$ in the body and feces.

\section{Discussion}

Animals exposed to sublethal levels of copper and/or cadmium and fed selenium-free diets had significantly low rates of feed consumption and specific growth. The reduction in growth rate might have been due to the body burden of copper and cadmium which can cause a reduction in feed intake and weight gain. A growth reduction in Salmo gairdneri was partly attributed to increased metabolic costs and reduced food consumption (Lett et al., 1976). Similarly, a reduced RNA:DNA ratio in copper-exposed Oreochromis mossambicus was attributed to the metal burden in tissues that caused low production of RNA for protein synthesis (James et al., 2000, 2004). Selenium supplementation improved the feeding and growth parameters, perhaps because it caused the removal of copper and cadmium. Heteropneustes fossilis exposed to mercury along with Eichhornia crassipes had significantly improved feed intake and growth over those exposed to mercury alone as the $E$. crassipes removed a considerable amount of mercury from the test medium (James et al., 1992a). In O. mossambicus exposed to cadmium/copper and an ion-exchanging agent, zeolite, metal was removed from the water and body tissues and the RNA:DNA ratio was subsequently improved (James et al., 2000, 2004).

The exposure of $C$. mrigala to sublethal levels of copper and/or cadmium resulted in a significant $(p<0.05)$ decrease in the RBC count and hemoglobin content, leading to anemia. The anemic condition may have been due to inhibited erythropoiesis and hemosynthesis and an increased rate of erythrocyte destruction (Wintrobe, 1978). The lower oxygen carrying capacity of blood in exposed $C$. mrigala might have been due to the reduced RBC count and $\mathrm{Hb}$ content. The oxygen carrying capacity of blood in $\mathrm{H}$. fossilis declined due to a reduced $\mathrm{RBC}$ count and $\mathrm{Hb}$ content, reflected in tissue respiration (James and Sampath, 1995). This might have been reflected in the reduced oxygen consumption of animals exposed to copper and/or cadmium. Similarly, precipitation of metallic protein on the gill surface and damage of gill architecture were attributed to the decreased respiratory rate in S. gairdneri exposed to heavy metals (Macleod and Pessah, 1973).

In the present study, the RBC count, $\mathrm{Hb}$ content, and oxygen carrying capacity of blood improved in exposed C. mrigala fed selenium supplemented diets, suggesting a protective role of selenium against metal toxicity in C. mrigala. Likewise, in Clarias gariepinus exposed to copper and fed a diet containing $0.3 \mathrm{~g} \mathrm{Se} / \mathrm{kg}$, the RBC count, $\mathrm{Hb}$ content, hematocrit, glucose, and total lipids were higher than in fish fed an unsupplemented diet (Abdel-Tawwab et al., 2007). In Nile tilapia, organic selenium supplementation enhanced growth and feed utilization and reduced susceptibility to Aeromonas hydrophila infection (Ahmad et al., 2006).

The tested physiological parameters were significantly affected in the exposed fish. Manifestations of these parameters were certainly signs of heavy metal toxicity, which was greatest when fish were exposed to the combination of copper and cadmium. The combination of $\mathrm{Cu}+\mathrm{Cd}$ was highly toxic due to a synergistic effect: $\mathrm{Cd}$ enhances the toxicity of Cu several-fold beyond that of Cu alone (James et al., 1992b). The synergistic effect of $\mathrm{Cu}+\mathrm{Cd}$ also significantly affected the survival, proximate composition, and respiratory enzymes in O. mossambicus (James et al., 1991, 1992b).

Selenium (Se) is an essential trace element, required in the diet for normal growth and physiological function of fish (Hilton et al., 1980; Bell et al., 1985). The inorganic form of selenium (sodium selenite or sodium selenate) is commonly used as a selenium supplement in livestock diets. Selenium also serves as a component of the enzyme glutathione, peroxidase, which protects cell membranes against oxidative damage (Rotruck et al., 1973). The present investigation shows that selenium in the diet of $C$. mrigala reduces copper and cadmium toxicity, and thereby enhances the tested physiological parameters. However, the amount of selenium required differed according 
to the toxic nature of each metal in the equitoxic combination. In conclusion, 75 and 225 $\mathrm{mg} \mathrm{Se} / \mathrm{kg}$ diet are required to reduce copper and cadmium toxicity, respectively, when only one of the metals exists in the environment but $300 \mathrm{mg} \mathrm{Se} / \mathrm{kg}$ diet is required to reduce $\mathrm{Cu}+\mathrm{Cd}$ toxicity when both metals are present together. While the present study shows that selenium dietary supplementation improves fish growth, further study is required to determine the amount of selenium required for different combinations of metals.

\section{References}

Abdel-Tawwab M., Mousa M.A.A. and Fayza E. Abbass, 2007. Growth performance and physiological response of African catfish, Clarias gariepinus (B.) fed organic selenium prior to the exposure to environmental copper toxicity. Aquaculture, 272:335-345.

Adhikari S., 2002. Distribution of different forms of copper in freshwater pond soils of Orissa, India. Isr. J. Aquacult. - Bamidgeh, 54(3):104-109.

Ahmad M.H., El-Marakby H.I., Seden M.E.A., Tawwab M.A. and M.E. Abou-ElAtta, 2006. The use of organic selenium (sel-plexo) in practical diets for Nile tilapia, Oreochromis niloticus (L.): effect on growth performance, feed utilization, whole-body composition and entropathogenic Aeromonas hydrophilla challenge. pp. 95-107. In: W. Contreras, K. Fitzsimmons (eds.). $7^{\text {th }}$ Int. Symp. Tilapia in Aquaculture, 6-8 September 2006, Boca del Rio, Veracruz, Mexico.

Bell J.G., Cowey C.B., Adron J.W. and A.M. Shanks, 1985. Some effects of vitamin E and selenium deprivation on tissue enzyme levels and indices of tissue peroxidation in rainbow trout (Salmo gairdneri), Brit. J. Nutr., 53(1):49-57.

Boyd C.E., 1990. Water Quality in Ponds for Aquaculture. Alabama Agri. Exp. Stn., Alburn Univ., AL. 482 pp.

FAO, 1975. Manual of Methods in Aquatic Environment Research, part I. Publ. Div. FAO, Rome. 223 pp.

Hardy R., 1980. Fish feed formulation. pp. 233-239. In: Fish Feed Technology. ADCP/REP/80/11, FAO, UN, Rome.

Hilton J.W., Hodson P.V. and S.J. Singer, 1980. The requirement and toxicity of selenium in rainbow trout (Salmo gairdneri). J. Nutr., 110:2527-2535.

James R., 2010. Effect of dietary supplementation of spirulina on growth and phosphatase activity in copper-exposed carp (Labeo rohita). Isr. J. Aquacult. - Bamidgeh, 62(1):19-27.

James R. and K. Sampath, 1995. Sublethal effects of mixtures of copper and ammonia on selected biochemical and physiological parameters in the catfish Heteropneustes fossilis. Bull. Environ. Contam. Toxicol., 55:187-194.

James R., Sampath K., Sivakumar V. and S. Manthiramoorthy, 1991. Individual and combined effects of heavy metals on survival and biochemistry of Oreochromis mossambicus. Indian J. Fish., 38:49-54.

James R., Sampath K., Jancy Pattu V. and G. Devakiamma, 1992a. Utilization of Eichhornia crassipes for the reduction of mercury toxicity on food transformation in Heteropneustes fossilis. J. Aquacult. Trop., 7:189-196.

James R., Sampath K. and K.P. Ponmani, 1992b. Effect of metal mixtures on activity of two respiratory enzymes and their recovery in Oreochromis mossambicus (Peters). Indian J. Exp. Biol., 30:496-499.

James R., Sampath K. and P. Selvamani, 1998. Effect of EDTA on reduction of copper toxicity in Oreochromis mossambicus. Bull. Environ. Contam. Toxicol., 60:487-493.

James R., Sampath K. and P. Selvamani, 2000. Effect of ion-exchanging agent, zeolite on removal of copper in water and improvement of growth in Oreochromis mossambicus (Peters). Asian Fish. Sci., 13:317-325.

James R., Sampath K., Jeyamary R. and P. Selvamani, 2004. Effect of zeolite (sodium aluminosilicate) on the removal of copper from water and fish and an improvement of RNA:DNA ratio in Oreochromis mossambicus. Ecohydrol. Hydrobiol., 4:57-65. 
James R., Sampath K., Thangarathinam R. and I. Vasudhevan, 2006. Effect of dietary Spirulina level on growth, fertility, coloration and leucocyte count in red swordtail, Xiphophorus helleri. Isr. J. Aquacult. - Bamidgeh, 58:97-104.

Johansen K., 1970. Air breathing fishes. pp. 361-411. In: W.S. Hoar, D.J. Randall (eds.). Fish Physiology, vol. IV. Academic Press, New York, London.

Lett P.F., Farmer G.J. and F.W.H. Beamish, 1976. Effects of copper on some aspects of the bioenergetics of rainbow trout Salmo gairdneri. J. Fish. Res. Bd. Can., 30:485-492. Litchfield Jr. J.T. and F. Wilcoxon, 1949. A simplified method of evaluating dose effect experiments. J. Pharmacol. Exp. Ther., 96:99-113.

Liu J. and G. Yang, 2009. Changes in copper content of allogynogenetic silver crucian carp after application of copper sulfate to fishponds. Isr. J. Aquacult. - Bamidgeh, 61(4): 351-355.

Macleod J.C. and E. Pessah, 1973. Temperature effects on mercury accumulation, toxicity and metabolic rate in rainbow trout, Salmo gairdneri. J. Fish. Res. Bd. Can., 30:485-492.

Rotruck J.T., Pope A.L., Ganther H.E., Swanson A.B., Haefeman D.G. and W.G. Hoejstra, 1973. Selenium: Biochemical role component of glutathione peroxidase. Science, 179:588-590.

Sprague J.B., 1973. The ABC's of pollutant bioassay using fish. pp. 6-30. In: Biological Methods for the Assessment of Water Quality. STP 528, Am. Soc. Testing Materials.

Welsh J.H. and R.I. Smith, 1953. Laboratory Exercise in Invertebrate Physiology. Burgess Publ. Co., Minneapolis, MN. 27 pp.

Wintrobe M.M., 1978. Clinical Haematology. H. Kimpton, London. 448 pp.

Zar J.H., 1984. Biostatistical Analysis, $2^{\text {nd }}$ ed. Prentice-Hall Int., Inc. Englewood Cliffs, NJ. pp. 224-260. 